\title{
Humanities PhD Graduates: Desperately Seeking Careers?
}

\author{
Lynn McAlpine \\ McGill University, University of Oxford \\ Nichole Austin \\ McGill University
}

\begin{abstract}
National and international statistics show that across disciplines there are many more $\mathrm{PhD}$ graduates than academic positions. In fact, more than half of graduates find their careers outside the academy-though the kinds of positions they accept, their work satisfaction, and the relevance of their PhDs is much less clear. As regards scholarly studies on post-PhD careers, most have examined social scientists and scientists with little attention to humanities doctoral graduates. This study addresses this gap by exploring the career experiences of Canadian PhD humanities graduates through descriptive statistics and narrative analysis. Specifically, it highlights the $\mathrm{PhD}$ experiences and post-graduation career trajectories of 212 Canadian humanists from 24 universities who graduated between 2004 and 2014. The study offers insight into humanities career challenges, including during the $\mathrm{PhD}$, the range of non-academic careers that humanists find, as well as their work satisfaction and the perceived relevance of the PhD.
\end{abstract}

\section{Résumé}

Tant sur le plan national qu'international, les statistiques montrent que le nombre de détenteurs de doctorat demeure nettement supérieur au nombre de postes académiques disponibles, et ce, toutes disciplines confondues. Alors qu'on observe que plus de la moitié des détenteurs de doctorat se retrouvent dans une carrière non académique, on en sait peu sur le type de postes qu'ils acceptent, leur satisfaction au travail et l'utilité de leur doctorat. La plupart des recherches menées jusqu'ici sur la carrière des détenteurs 
de doctorat concernent les sciences sociales ou les sciences exactes, laissant généralement dans l'ombre le champ des Humanités. La présente étude aborde précisément l'expérience de carrière de détenteurs de doctorat dans ce champ en s'appuyant sur des statistiques descriptives et des analyses narratives. Plus particulièrement, il est question de l'expérience doctorale et du parcours de carrière postdoctoral de 212 détenteurs de doctorat dans le champ des Humanités ayant diplômé entre 2004 et 2014 dans 24 universités canadiennes. La présente étude offre un aperçu des enjeux propres à la carrière dans les Humanités, incluant les défis rencontrés durant les études doctorales, la variété de carrières non académiques dans lesquelles se retrouvent les détenteurs de doctorat ainsi que leur satisfaction au travail et leur perception de l'utilité de leur doctorat.

\section{Context}

Reports of the experiences of humanities doctoral students are relatively rare (Leonard, Metcalfe, Becker, \& Evans, 2006). Further, studies of post-PhD career-related experience, regardless of discipline, are also rare (Kyvik \& Olsen, 2012). This study addresses this gap by reporting the career hopes and outcomes of Canadian post-PhD humanities graduates. This study is of particular importance given national and international statistics showing that across disciplines there are many more $\mathrm{PhD}$ graduates than academic positions (Neumann \& Tan, 2011). So, more than half of graduates will end up finding their careers outside the academy - though the kinds of positions they accept, their work satisfaction, and the relevance of the $\mathrm{PhD}$ is much less clear.

The humanities have been conceived as distinct from the sciences and social sciences (Becher \& Trowler, 2001), with their signature PhD pedagogies (Jones, 2008, p. 37) resting on a "long tradition of individualism." Emphasized are teaching and solitary scholarship: the need to know the "canon" in order to teach, the opportunity and flexibility to choose one's own project, and independence as a researcher in undertaking the thesis (Jones, 2008; Golde, 2005). While there is variation by department, programs in North America often involve two to three years of full-time course work, canonical exams, and concurrent teaching requirements before undertaking the dissertation. The challenge of this choice and independence can be relatively infrequent contact with the supervisor, isolation from peers, and a long time to obtain the degree.

As of 2009-10 (the most recent year for which national data are available), the absolute number of doctoral degrees granted from Canadian institutions had risen steadily, from nearly 4,000 in 1988, to 5,421 in 2008, to 6,600 in 2010 (Statistics Canada, 2012; Desjardins \& King, 2011; Ferguson \& Wang, 2014). Yet it has been estimated that only 1,500 to 2,000 tenure-track positions are advertised annually (Chiose, 2015).

While over half of all Canadian master's degree recipients in the humanities opt to pursue additional education (surpassing the proportion in most other fields), only 500 of the 6,600 PhDs awarded in 2009-10 ( 8\%) were in the humanities (Desjardins \& King, 2011; Statistics Canada, 2013). Further, whereas most PhD programs have grown substantially over the past decades, in the humanities, PhD student enrolment fell from $16 \%$ in 1992 to $11 \%$ in $2008^{1}$ (Association of Universities and Colleges of Canada, 2011). 
Though there are few studies of humanities doctoral experience, humanities faculty have been struggling with whether and how to redefine themselves given dramatic changes in popular culture, publishing, and the job market for graduates: "The English doctorate [a signature humanities discipline] needs to be rethought from the ground up" (Graff, 2006, p. 372). In other words, well before the global economic crisis, questions were being raised about how humanities disciplines might change their doctoral practices. Despite these conversations, internal efforts to undertake curriculum reform have proved difficult (Golde \& Walker, 2006).

Moving beyond the humanities specifically, a shift in knowledge production is challenging the traditional nature and value of research (Gibbons et al., 1994; Nowotny, Scott, \& Gibbons, 2003). This "Mode 2" knowledge values application, flexibility, and responding to external demand, so tends to emphasize research with instrumental and commercial value over curiosity-driven research. Further Mode 2 research criteria include competitiveness, cost effectiveness, and social acceptability. This shift means that besides being good researchers, individuals need to be team leaders, managers, and marketing experts (Melin \& Janson, 2006). Graduates in science, technology, engineering, math, and medicine are perceived as being able to take advantage of this shift more easily than those in the social sciences and humanities, for instance, through the development of patents and start-up companies.

Though some, like Hessels and Lente (2010), have argued that the empirical evidence supporting Mode 2 is weak and the construct lacks conceptual strength, the notion of Mode 2 knowledge has been taken up broadly by universities. For instance, at the doctoral level, institutional training initiatives emphasize "generic" or "transferable" skills (teaching, communication, teamwork in non-academic contexts, and career development) (Maheu, 2006) to better prepare PhD students for a range of non-academic careers - see the Pathways Program at the University of British Columbia and the Future Smart Program at Ryerson University. Many other universities refer students to websites and other external resources for non-academic job preparation, which may be insufficient. Unfortunately, evaluation of the impact of such training is negligible, though Jackson and Michelson (2015) report a lack of influence on post-PhD employment.

Given this range of influences on doctoral experience, understanding how humanities $\mathrm{PhD}$ graduates experience their programs and situate themselves in today's labour market is of fundamental concern and could help humanities doctoral programs rethink their offerings, and students their career plans.

With this as background, we next explore previous reports as to factors relevant to career decision making, both during doctoral study and afterwards, referring to the humanities as much as possible.

\section{Doctoral Experience}

Over the past 15 years, three themes have remained constant in doctoral education: (1) time to completion, largely a policy concern; (2) funding, a policy and student concern; and (3) career preparation, largely a student concern-which we characterize as an aspect of training. 


\section{Time to Completion}

Doctoral completion rates in the humanities (and social sciences) have been seen as a problem for 15 years or more (Yeates, 2003; Elgar, 2003). The term "completion" incorporates what may appear to be lack of completion (but may be a change of university or noninstitutional leave), as well as time to completion. The latter has traditionally been lengthier in the humanities in comparison with the social sciences, but particularly so with the sciences. Still, discipline is not the only factor: departments that support prompt completion tend to have completion times shorter than programs in the same disciplines that do not (Gardner, 2009). Attending to completion encourages departments to remain aware of student progress and offer support as needed. Still, a focus on time to completion is misdirected if funding is inadequate and the careers for which graduates have prepared are not available.

\section{Funding}

Over 15 years ago, Golde and Dore (2001) noted that many students were unaware of the financial implications of doctoral study prior to enrolment, and students, particularly in the humanities, accumulated significant debt in graduate school. We noted faculty concern about funding several years later among English academics in Canada (McAlpine, Paré, \& Starke-Meyerring, 2008). Faculty were challenged with generating funding strategies to both attract and support students. First, national (and in some cases, provincial) doctoral funding was only for three years, and this was insufficient time for students to develop their academic profiles. Further, such funding was available to only a few. As well, these faculty members argued that the humanities were not benefiting from the same level of university funding as the sciences, so they could not compete for the best students against other universities offering more generous financing. Their response was to create studentships by, for instance, pulling together different teaching opportunities to make up a TA-ship.

\section{Training}

Teaching is a core humanities practice. Still, as Golde (2005) noted, teaching often provides core doctoral funding, which is provisional and short term. Further, once teaching becomes bound up with funding, teaching may override other doctoral tasks and impede progress (Gardner, 2009). As a result, when humanities students report feeling overworked and exploited, it is usually a reference to the number of hours spent teaching or grading papers (Zhao, Golde, \& McCormick, 2007). So, despite faculty awareness of the problem and attempts to address it, funding remains an issue since adequate student funding influences students' overall satisfaction (Harman, 2002), and lack of adequate funding, leading to indebtedness, influences research productivity which can impact career options (Yang \& Webber, 2015).

As for career preparation, students have consistently reported a desire for better career preparation (Golde \& Dore, 2001). This theme has gained prominence over time, with a recent study reporting that humanities graduates who found themselves in nonresearch jobs post-graduation wished they had had better career preparation (Kyvik \& Olsen, 2012). Interestingly, while training to address Mode 2 trends, including career preparation, has become an institutional concern, students report a limited understanding of 
their prospects (Thiry, Laursen, \& Loshbaugh, 2015). Lastly, though doctoral students wish for career preparation, they rarely engage in career-seeking strategies (McAlpine \& Amundsen, 2016). This is unfortunate since engaging in job-search strategies during the degree, such as using career services and networking, substantially increases success in gaining prompt employment post-PhD (Jackson \& Michelson, 2015).

In our earlier study (McAlpine et al., 2008), humanities students and graduates were most concerned about their futures: "We're being groomed for tenure-track positions and they don't discuss other options." While these individuals would have liked tenure-track positions, they realized this was unlikely (Desjardins \& King 2011). Of course, the lack of appropriate career preparation was not limited to this department or discipline. Notably, Zhao and colleagues (2007) reported that humanities students were less likely than those in the physical, biological, and social sciences to report supervisor behaviours that would develop their careers. Overall, not only is doctoral career preparation insufficient, there is consistent evidence that it may not prepare graduates for the kinds of jobs they find. In other words, there is a potential mismatch between the traditional, implicit purpose of doctoral education (as enacted in programs) and the realities of students' careers post-graduation.

\section{Post-Graduation}

The two themes of post-graduation-lack of academic positions and increasing job insecurity-have grown over time.

\section{Lack of Academic Positions}

While many $\mathrm{PhD}$ students imagine research-teaching positions, at least when starting their degrees, humanities $\mathrm{PhD}$ students tend to imagine this to be the case more so than students in other disciplines (Kyvik \& Olsen, 2012; Maldonado, Wiggers, \& Arnold, 2013). While it is true that humanities graduates have more employment in higher education than other fields (Auriol, Misu, \& Freeman, 2013), such reports often do not distinguish between academic and other forms of employment within the sector (Neumann \& Tan, 2011). In fact, the data are disturbing. An analysis of 2011 National Household Survey data found that despite $39.4 \%$ of doctorate-holders working in the post-secondary education sector in some capacity, only $18.6 \%$ were working as full-time university faculty (Edge \& Munro, 2015, pp. 16-17).

\section{Increasing Job Insecurity}

Further, the evidence internationally paints a sorry picture with regards to the financial stability of the positions that humanities graduates find, regardless of sector:

- Humanities graduates in Canada show higher rates of both unemployment and part-time employment compared to graduates in other fields, as well as slightly below-average median earnings (Desjardins \& King, 2011).

- Humanities graduates in the European Union experience higher unemployment than those in engineering and science (Boulos, 2016).

- Overall, those in the humanities in representative countries of the Organisation for Economic Co-operation and Development have a higher rate of temporary contracts than those in other disciplines (Auriol et al., 2013). 
In addition, at least two analyses highlight how the global economic crisis has influenced the labour market for humanities graduates: ${ }^{2}$

- In the United Kingdom, humanities graduates have been most affected, in comparison to other disciplines, by the global crisis: higher proportions in part-time employment and non-academic employment; a faster-rising proportion on fixedterm contracts; and higher levels of "portfolio" work (Mellors-Bourne, Metcalfe, \& Pollard, 2013).

- In the United States, the same trend is evident: history PhD graduates who graduated in 2006-09 hold fewer tenure-track positions than earlier cohorts; rather, there has been a dramatic increase in non-tenure-track positions (Maren Wood, 2012).

The very few studies of potential employers outside the academy suggest challenges for all $\mathrm{PhD}$ graduates in finding non-academic employment. For instance, Kyvik and Olsen (2012) report that three-quarters of employers in private industry did not believe a PhD adds value beyond that of a master's degree, so $\mathrm{PhD}$ graduates may feel underemployed if hired (Pedersen, 2014). Interestingly, private employers who have already hired PhD graduates are more open to hiring them than those without such previous experience, as are employers with a research and development focus (Cruz-Castro \& Sanz Menendez, 2005).

We hope this review offers insight into how doctoral experience and post-PhD career trajectories have been characterized over the past 15 years, particularly with regards to the humanities. It is evident we need to understand retrospectively how humanities $\mathrm{PhD}$ graduates report their PhD experiences in light of their career trajectories.

\section{Research Questions}

Two broad questions guided the analysis:

1. In retrospect, how do humanities PhD graduates characterize their doctoral experience?

2. What career trajectories have they experienced post-PhD?

\section{Method}

\section{Project Overview}

The TRaCE (Track, Report, Connect, Exchange) study was a one-year pilot project designed to collect and summarize data on Canadian PhD humanities graduates. It was a rare inter-university collaboration between faculty and students at 24 universities across Canada. Ethical approval for TRaCE was granted by McGill University and from other participating universities as needed.

The design captured both quantitative and qualitative data on $\mathrm{PhD}$ humanities graduates with two overlapping and complementary stages. In the first stage, the participating institutions selected departments (typically two in the humanities) for inclusion in the study. The goal of the first stage was for participating departments to compile basic identifying information (including names, year of graduation, and dissertation titles) on all $\mathrm{PhD}$ graduates from 2004 to 2015 and forward this information to the central TRaCE office. The goal of the second stage was to supplement these basic data with qualitative accounts of the PhD and post-graduate experience by conducting a series of interviews. We are drawing on the data from this second stage. 


\section{Data Collection}

To streamline data retrieval and subsequent analysis, the investigators created data collection templates for both stages of the study.

Stage 1: Research assistants (RAs) used the departmental lists to search public electronic employment/ professional profiles (i.e., LinkedIn) to gather supplementary data on graduates' current occupations and geographic locations. These department-level datasets were subsequently cleaned and merged to create a de-identified master file for analysis; results are available at www.iplaitrace.com. The total number of graduates was 2,782.

Stage 2: TRaCE RAs, distributed across several universities, used the Stage 1 lists of graduates to contact potential participants; the central office provided email templates (in French and in English) to facilitate this process. All RAs received basic training in data collection and interview methods, and the central office provided training webinars, quick reference guides, and ongoing support throughout the data collection process.

When a graduate was willing to be interviewed, the RA secured informed consent and scheduled a convenient meeting time. Structured interviews were conducted in either English or French (depending on interviewee preference) in three modes: face-to-face when possible, as well as Skype or telephone. The interviews ranged from approximately 20 minutes to over an hour (average time: $\sim 45$ minutes). The interviews were not recorded due to (1) concerns that potential respondents might hesitate to participate, and (2) additional (and fairly extensive) ethical requirements for the use and storage of interview records, which were beyond the scope of a pilot project. Rather, RAs took notes during the interviews on a template, using acronyms and abbreviations to capture key words and phrases, and fleshing these out immediately afterwards. Participants were asked questions related to each of these domains: teaching, funding, mentorship, professional development, time to completion, employment after study, and reflections/research. In total, 321 graduates (or $12 \%$ from the master list) consented to be interviewed.

\section{Analysis}

Overview: To answer Research Question 1, we used the whole data set to present descriptive statistics and complemented the explanation with qualitative data. Given a relatively equitable distribution of graduates per year from 2004 through to 2014 (see Figure 1 below), to answer Research Question 2, we analyzed the results qualitatively for three years to overview career outcomes through the decade: 2004 the earliest graduation time in our data; 2009 mid-way through the time period and after the economic crisis; 2013 near the end of the period but with time post-graduation to have engaged in job searching. So while the sample size is small for each year, we capture some of the variation over time regarding post-PhD careers, of particular interest since the global economic crisis occurred during this period.

Process: As the interviews were completed, all researcher interview records were uploaded into university-specific folders stored on the file-hosting service Dropbox, to which only the RAs from each institution and the central office had access. The master data file was stored in a password-protected folder and was only accessible to the core team. Interview records were initially reviewed by the quantitative analyst, who tracked key points/ statements in each interview and created several binary or categorical indicator variables 
to more easily assess factors like family composition, time to completion, equity issues, and the general tone of the interview. This coding was viewed as a first-level analysis with the goal to organize the notes of the interview before subsequent, more fine-tuned coding. In this process, records with extensive missing data were excluded from analysis.

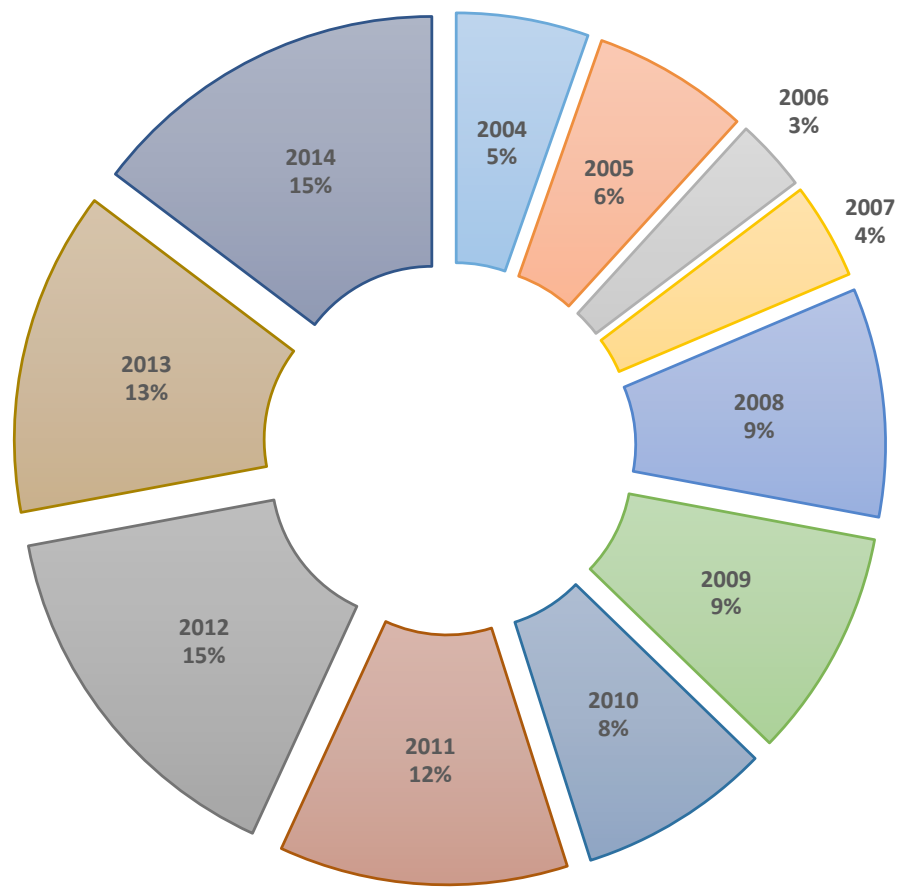

Figure 1. Interviewee distribution by year of graduation (2004--2014)

The interview process was still ongoing at the time of this initial analysis. In effect, a preliminary coding scheme was developed after the first 10 transcripts; this scheme evolved over the remaining review. Data saturation was reached when $75 \%$ of the interview transcripts available at the time (ultimately $66 \%$ of the final set of interview records) had been reviewed and coded in a summary file. This summary file included the responses from 212 interviewees and provided the basis for the analysis in this paper. While the selection of transcripts for analysis was not random (institutions with a complete set of interview records early in the review process were over-represented), the analyst ensured that the summary file contained adequate regional, provincial, and institutional variation.

Subsequently, the 212 interview responses were imported into qualitative analysis software and analyzed both thematically (Sfard \& Prusak, 2005) and narratively (Reissman, 2008). The decision to analyze the responses in these two ways was premised on these assumptions. Given the relatively large sample, it was appropriate to seek common themes or patterns across respondents. However, focusing solely on common themes would ignore the fullness and complexity of individual's experiences and decisions, which a narrative approach would help us represent. In order to construct such cameos, we first analyzed all data related to each participant in the pertinent year. From this review, individuals whose experiences appeared representative of the group were chosen, while preserving variation in the elements related to historical time and individuals' career experiences and motivations within their particular life contexts (McAlpine \& Amundsen, 
2016). Using the data and interviewer notes, short narrative cameos were constructed using a structured approach that captured the commonalities and variation consistently in order to compare accounts. ${ }^{3}$

\section{Participant Demographics}

Of the 212 individuals in the sample, nearly one-half represent English and one-fifth represent history, both signature humanities (13\% did not specify their discipline). Few of the interviewees (2\%) described their degrees as interdisciplinary (though this might have increased if graduates had been asked directly), and few experienced supervisory difficulties (5\%). Approximately 52\% were female and $48 \%$ were male (based on the 180 participants for whom data on sex were available). About one-quarter had children.

\section{Limitations}

There are several limitations that we expect to mitigate in future iterations. There is a possible selection bias: those who agreed to be interviewed may differ from those who were not interviewed, so may not be representative of all humanities graduates. With regards to the interview records, despite virtual training, the nature and quality of the interviews and note-taking were bound to vary since they were conducted by individuals in different institutions. Further, since the interview followed a structured protocol, there was little follow-up or probing. Lastly, data on race and ethnicity were not captured, and other demographic data, such as family leave, part-time status, and international status, were not consistently collected. And, of course, there is subjectivity inherent in any qualitative analysis, despite the authors' joint efforts to reach consensus. Still, we believe this study provides insights into humanities graduates' experiences that is not available elsewhere.

\section{Results}

\section{Research Question 1: How do humanities PhD graduates characterize their doctoral experience?}

Before examining the results, we introduce the cameos of two participants ${ }^{4}$ whose experiences we will refer to as we report the results.

Isabel began a $\mathrm{PhD}$ in literature after professional experience in editing. She completed the degree in 2014 after seven years, including a leave of absence. During this time, she also raised three children. Though she had four years of internal funding, this was inadequate, so she applied for external grants without success. Her teaching was limited: she TAed once in a corrector-ship and taught a workshop a few times. Her doctoral experience was "mixed," with many supervisory obstacles; in fact, she changed supervisors three times. Still, the administrative staff were supportive and a key to her success. While not feeling part of the departmental community, she did feel connected to the part-time faculty. Since graduation, she has become a freelance editor after forming her own company and feels the $\mathrm{PhD}$ made her a better editor. She has also had regular teaching contracts. In looking back, she wishes she had known the organizational issues in her department, and realizes that each $\mathrm{PhD}$ student has to have a plan. 
Rob completed his PhD in English in 2009 after eight or nine years of study, which he considered too long. During that time, he moved, had a child, and was an active volunteer. While he benefited from external as well as internal funding, he felt fortunate to live in a city that was relatively inexpensive. His family responsibilities led to a lack of focus and he often thought of quitting but his supervisor dissuaded him. He felt well mentored and a part of the community. During the degree, he had three TA-ships and did some contract teaching. So, he learned to put materials together quickly and gained confidence in his teaching. After graduating, he got a contract academic job, which led to his current full-time position-though he is still not permanent. He has found it tough to invest in his departmental community when not sure of his future, but expects this will change when he becomes permanent. While his $\mathrm{PhD}$ focus is not "super relevant" to his current job, he knew what he was "signing up for."

Time to completion: Both Isabel and Rob experienced lengthy times to completion, but some individuals finished in extremely short periods of time. In fact, the time to completion varied from three to 11 years. (It is unclear whether individuals included a master's degree in their reporting.) Contrary to traditional assumptions about lengthy times to completion in the humanities, nearly half (47\%) completed within five years: $19 \%$ in less than five and $28 \%$ in five. With regards to the remainder, $30 \%$ finished in six years. For those taking longer, $14 \%$ finished in seven years, $5 \%$ in eight years, and $4 \%$ in nine to 11 years. Eight individuals did not provide this information.

Individuals were asked to recount what had helped and what had hindered completion times. Whether positive or negative, the named factors could be characterized as either work/research or personal life factors. Supportive factors were sufficient funding, supervisory support, and family support. Hindering factors were the reverse. Those reporting six or more years to completion named the following academic-related reasons influencing time to completion: changing topic, teaching taking time away from research (but often considered worthwhile), failing the comprehensive exams, changing departments/programs, learning required languages, department restructuring, change/death of supervisor, and being part time. Lack of funding was both a hindering and a helping factor, depending on the stage of completion-during the degree, taking on paid work slowed progress, though near the end, individuals pushed to finish in order to be able to secure a more stable income.

More than half of those taking six or more years, 56 of 104 (54\%) noted these personal life factors affecting time to completion: maternity leave, managing children, moving, dealing with illness and family crises, and financial duress, which meant having to work. These factors have been previously reported for early career social scientists and scientists (McAlpine \& Amundsen, 2016). Often, interaction between personal reasons and work factors influenced the nature and degree of investment in work and career decision making; for instance, one interviewee took eight years and reported this as too long, but the death of a parent and the teaching load (valuable experience) added time.

Funding: Funding has generally been viewed as a relatively important factor in students' overall satisfaction (Harman, 2002). Interestingly, 93\% of the 212 interviewees reported some form of funding-higher than might have been expected: $59 \%$ reported 
both internal and external funding, 30\% internal only, 4\% external only, $5 \%$ reported no funding, and $2 \%$ no response. Still, the notion of "funding" needs unpacking. While some reported feeling well funded, this was not the general response. Even those with both external and internal funding still sometimes reported not having enough to live on. Recall Isabel's seeking more funding and Rob's comment regarding living in an inexpensive city.

Research council and university policies also came into play. For instance, some were excluded from certain kinds of funding due to their international or part-time status. Further, students reported that their internal funding was reduced when external funding was awarded. Also, funding came and went over the years since the funding was awarded for varying amounts of time. Lastly, many reported only getting external funding for short periods of time near the end to help them finish. The overall picture that emerged is one of insufficient financial support for many students, with internal funding often consisting of TA-ships.

Training: Teaching was the most common Mode 2 skill referred to. As is common in the humanities (Golde, 2005), teaching of some type was part of nearly all interviewees' $\mathrm{PhD}$ experience (94\%) with $65 \%$ both TAing and teaching, $15 \%$ teaching only, and $13 \%$ TAing only. Of the 13 who did not teach, reasons included Social Sciences and Humanities Research Council of Canada requirements, lack of departmental opportunity, or policies limiting PhD teaching. A couple felt no need to teach given prior teaching experience, and five reported choosing not to teach in order to focus on their work. (There were three cases of non-response.)

Overall, opportunities to teach were highly valued. Yet teaching responsibilities were often described as competing with time for research work, as reported earlier (Zhao et al., 2007). In other words, teaching can be a double-edged sword-appreciated for itself and its instrumental financial support, but directing attention away from the primary focus of the PhD. As well, access to teaching varied, as noted in the difference in experience between Rob and Isabel.

Other training was rarely mentioned. Rather, individuals reported training they would have liked, particularly career preparation and writing support, with frequent mention of the lack of preparation for the non-academic labour market. While mindful that these comments are post hoc, they are consistent with previous reports in the literature (Kyvik \& Olsen, 2012). With this as background, we explore the careers individuals found.

\section{Research Question 2: What career trajectories have they experienced post- PhD?}

As noted earlier, to answer this question, we drew on three years from 2004 to 2014: 2004, 2009, and 2013. We wanted to explore the variation over time regarding post-PhD career trajectories, since the global economic crisis occurred during this period.

2004: 9 of 11 in tenure-track positions: Eleven respondents graduated in 2004.

- Nine of them are tenured now as associate or full professors, most in Canada. They held postdocs or sessional positions immediately after graduation.

- Two women chose to prioritize family and expressed satisfaction with the decision: one holds a part-time faculty position, good for childcare; the other works as a freelance academic editor because she didn't want to relocate for a tenure-track position. 
Tom's story gives a sense of the experiences of these individuals who graduated well before the global economic crisis and found research-teaching positions. Tom's experience highlights the challenges even before the economic crisis of getting an academic position.

Tom did a PhD in philosophy, graduating in 2004. As an international student, he was ineligible for external funding. Despite some internal fellowships, these were insufficient, given his family. So, he worked externally and focused on finishing, which he did in four years. He wanted to do it faster, but was advised to slow down, which allowed for extra reading. Unfortunately, there was no organized support for teaching, writing, or research, but faculty were open to conversations and willing to help. He engaged in interdisciplinary work though the department was originally wary, and this work eventually paid off. Given he was older and driven to finish, he had little involvement in the scholarly community. After completing he did two postdocs. He sent out $60 \mathrm{CVs}$ and was offered a tenure-track job in the U.S., but it was a poor fit. He sent out 10 more CVs and got the job he wanted. Currently, he is a full professor and is shifting his career away from philosophy so that his work can have a more immediate impact on humankind.

\section{9: 8 of 19 in tenure-track positions: Nineteen graduated in 2009.}

- Eight were in tenure-track positions, two in other countries, most after a number of years spent searching for a job.

- Two others worked within the academy: one teaching, the other in administration.

- Seven worked outside academia; jobs varied, including e-learning developer, museum or art curator, communications officer, and freelance consulting. Work was sometimes "portfolio," for instance, "now self-employed...do programming for film festival, teach part-time at college level, and translate."

- Two were unemployed: one looking for teaching positions in the academy and the other looking outside the academy.

Phil's experience shows that obtaining an academic position was more difficult in 2009 than in 2004, and international mobility was an asset. Kellan's story demonstrates the growing challenge of finding even a non-academic position.

Phil did a PhD in History, graduating in 2009. He chose the program (for him, using English as another language) to work with two prominent scholars; one supervised him. He felt well supported by the two and had provincial funding as well as many internal grants. He felt rewarded for publishing, seeing the awards as a reflection of his effort. Given the diverse scholarly community, he learned to interact with students from all over. He completed in six years. While he could have finished faster in Europe, North American universities provided better preparation for the academic job market, though without formal job preparation. He then did two postdocs in Europe and taught while job-searching for six years before getting his current tenure-track position in the Far East. Overall, the job search was frustrating and he sometimes considered changing paths. He wishes, looking back, he had known that the lack of prestige of his PhD university would set him back in the job search (Jackson \& Michelson, 2015). Nevertheless, he feels good at what he does and loves the work. 
Kellan completed his PhD in literature in 2009. He had "generous" internal funding and supplemented this with part-time work. While his supervisor provided some mentoring, he lacked a sense of community as he was in a "free-floating" interdisciplinary program. He would have preferred a more disciplined program. He also found it hard to get going on the thesis before completing the comprehensive exams. So, it took Kellan seven years to complete the $\mathrm{PhD}$. He wished it had been five and felt that, with more focus, he could have been faster. Afterwards, it was tough to find work. He couldn't get a postdoc, so he moved and worked various miscellaneous jobs, such as retail. He eventually found a position as a communications officer. While his $\mathrm{PhD}$ research isn't relevant to his current job, some skills have transferred. Looking back, he says that basically he did the $\mathrm{PhD}$ because he didn't know what to do after his master's. He didn't think about the "endgame" and wishes he had had a clearer idea about his goals before the $\mathrm{PhD}$.

2013: 3 of 27 in tenure-track positions: Twenty-seven students graduated in 2013. While the number of participants in academic positions might be influenced by data being collected only two to three years after graduation, the positions individuals have found suggests they are not seeking tenure-track positions.

- In contrast with those graduating in 2004 and 2009, only three are in tenure-track positions.

- Three are working as professionals in the academy, such as research coordinator or financial aid administrator.

- Another four are teaching, often on contract and sometimes in more than one university, and one on the job market had been offered a limited-term contract.

- Six are working as researchers in the academy, one part time.

- Outside the academy, 10 are largely consultants: working freelance as writers, editors, managers, or teachers in college or high school. Their careers are generally "portfolio."

Overall, there is a greater sense of insecurity and improvisation than in the 2009 cohort. Given the size of the group, we offer three cameos to show the range of career trajectories: Maria is an academic administrator, since seeking an academic position was not worthwhile to her; Ben is self-employed in a portfolio career; and Kelsey is creating her own career through starting a business.

Maria graduated in 2013 with a PhD in English. She had external and internal awards, without which the degree would have been impossible, since it let her focus on her research. She felt she was a part of the department, noting peers helped each other, but life outside the PhD community was important. She had a good relationship with her responsive and professional supervisor. Still, health problems and isolation were obstacles. Access to isolation-reducing writing support and more guidance regarding careers would have helped. Completing the PhD after four years, she got a job in university administration, since continuing towards an academic position didn't seem worthwhile. She currently works as a senior advisor in the financial aid office, work with little relevance to her PhD. Life outside of work continues to be important. Looking back, she notes the academic job market doesn't accommodate people without a single-minded dedication to the field. For 
her, it was important to weigh her quality of life against the intellectual satisfaction of an academic life. As a result, she has no regrets about doing the $\mathrm{PhD}$ or opting out of an academic position.

Ben completed his PhD in art history in 2013. His external and internal funding was very helpful and his three RA-ships very connected to his research. He received a lot of mentorship from his supervisor and other faculty members, particularly with regards to research and job seeking, and he felt a part of the community. He continued his art practice throughout the degree, which took him five years. This was slightly longer than he had hoped due to health issues. The other obstacle was perfecting his French since he was in a bilingual program. While the funding helped him complete in a timely fashion, he found departmental benchmarks were also helpful. Post-PhD, he worked first as a postdoc, then on a limited-time teaching appointment. Now he is an occasional freelance writer while continuing his art practice. He describes his $\mathrm{PhD}$ work as very relevant. In looking back, he wishes there had been a formal thesis-writing group since this would have helped galvanize people, including him, and improve time to completion.

Kelsey graduated in history in 2013. She had internal funding but worked to make ends meet. Still, her supervisor was "amazing" and willing to talk about non-academic jobs. She also had good relationships with those in her program. So, while the PhD was independent, she felt supported. The degree took her seven years and she's not sure she could have done it faster since she had to work, plus do her overseas study. She was motivated to finish by two things: her supervisor's support and the lack of funding. After graduation, she immediately went on maternity leave. Once ready to work, she became a business manager in a non-profit. She is now organizing her own business. In looking back, while the content of her PhD research is not presently relevant, the skills she developed are. She also learned that "you just have to stick with it" since the sense of accomplishment is amazing. While the $\mathrm{PhD}$ helped her figure out what she wanted to do, she feels people should think about their careers and preferred locations before graduating.

We expect you can see a range of common themes across these stories. What we would highlight is the variation in agency: from strategic and goal-oriented to retrospectively recognizing the lack of such strategies (McAlpine \& Amundsen, 2016).

\section{Discussion}

We argued initially that evidence collected over the past 15 years in different countries demonstrates that doctoral education is not preparing graduates for the kinds of jobs they find-though humanities graduates were little studied. This research adds to that picture by contributing a current, as well as retrospective, picture of the career paths of Canadian humanities PhD graduates. Individuals generally had positive experiences during their degrees-positive supervision, a sense of community if they wanted it, opportunities to teach. Still, since funding was insufficient, they had to find additional work to make ends meet.

While slightly more than $50 \%$ of students took five or more years to completion, this situation was often influenced by a tsunami of institutional (departmental restructuring), 
research (change of supervisor), and personal (personal illness) challenges. This finding parallels social science and science doctoral experiences (McAlpine \& Amundsen, 2016). This mix of factors is a reminder that while time to completion is often perceived as a "student" problem, it may actually rest in departmental issues (Gardner, 2009).

In relation to institutional initiatives related to Mode 2 knowledge production, while teaching (one transferable skill) was seen as valuable, it also took large amounts of time away from PhD progress (Gardner, 2009). Regarding other possible training, there were multiple comments about the lack of alternative career preparation (Kyvik \& Olsen, 2012), though a number noted they could have been more agentive in this regard. They also desired more training on communication, particularly writing. So, if universities are offering such provision, it may not be easily visible to students.

Concerning the post-PhD careers of participants, fewer than half are in tenure-track positions, with proportionally more in such positions in 2004 than at the two later times. Further, and more recently, individuals in other positions-whether in and out of the academy-were on contract, working freelance, or unemployed. This state of financial insecurity matches the reports of humanist trajectories in other countries, including the impact of the economic crisis (Mellors-Bourne et al., 2013; Maren Wood, 2012). Interestingly, while those not in academic positions regretted the lack of career support and career planning during their degrees, and felt the substance of their $\mathrm{PhD}$ research was not relevant, the skills they had developed were relevant. While we recognize that their perceptions may be influenced by a desire to create coherence and purpose in their life stories (Taylor, 2008), the finding suggests the need for a serious examination of what skills the humanities $\mathrm{PhD}$ is developing-and how these can be explicitly articulated as a form of career support. Overall, one is left with a sense of the need for much more research, particularly with regards to the range of career options available, both in and outside the academy, and the skills that these positions call for.

Finally, concerning whether or not individuals felt able to draw value from their PhDs in the non-academic labour sector, the answer is a cautious "yes" with a relatively large number saying they could see ways in which they drew on skills they developed during the degree. While such comments should encourage institutions and PhD programs to think more coherently about the nature of the career support offered to humanities students, as we have argued elsewhere (McAlpine \& Amundsen, 2016), it should also be a prompt to doctoral students to develop their own career strategies early on.

\section{Conclusion}

As noted initially, reports of the experiences of humanities doctoral students are relatively rare, and studies of post-PhD career-related experience, regardless of discipline, are also rare. Our study addressed this gap by reporting the $\mathrm{PhD}$ and post-graduation career trajectories of Canadian humanities $\mathrm{PhD}$ students from 24 universities who graduated between 2004 and 2014. It demonstrates how the lack of both funding and career preparation continues to pervade $\mathrm{PhD}$ experience, the range of non-academic careers that these humanists have found, as well as the perceived relevance of the PhD. Still, much more research is necessary. 


\section{Notes}

1. The most popular fields were the sciences (22\%); then social sciences, behavioural sciences, and law (20\%); and architecture, engineering, and related technologies (16\%).

2. No Canadian data could be found.

3. See McAlpine (2016) for a fuller explanation of the approach.

4. The names of all participants are aliases.

\section{Acknowledgements}

We would like to thank the individuals who willingly shared their $\mathrm{PhD}$ and post-PhD experiences and made this study possible.

\section{References}

Association of Universities and Colleges of Canada. (2011). Trends in higher education: Enrolment. Ottawa, Canada: Association of Universities and Colleges of Canada.

Auriol, L., Misu, M., \& Freeman, R. (2013). Careers of doctorate holders: Analysis of labour market and mobility indicators.Paris, France. OECD Publishing.

Becher,T., \& Trowler, P.(2001).Academictribes and territories (2nd ed.). Buckingham, UK: Open University Press.

Boulos, A. (2016). The labour market relevance of PhDs: An issue for academic research and policy-makers. Studies in Higher Education, 41(5), 901-913.

Chiose, S. (2015, March 6). For 10,000 of Canada's young academics on the picket lines, there's a lot more at stake than $\$ 42$ an hour. The Globe and Mail. Retrieved from http:// www.theglobeandmail.com/news/toronto/for-1000o-of-canadas-young-academics-onthe-picket-lines-theres-a-lot-more-at-stake-than-42-an-hour/article23346532/

Cruz Castro, L., \& Sanz Menendez, L. (2005). The employment of PhDs in firms: Trajectories, mobility and innovation. Research Evaluation, 14(1), 57-69.

Desjardins, L., \& King, D. (2011). Expectations and labour market outcomes of doctoral graduates from Canadian universities. Ottawa, Canada: Statistics Canada.

Edge, J., \& Munro, D. (2015). Inside and outside the academy: Valuing and preparing PhDs for careers. Ottawa, ON: The Conference Board of Canada. Retrieved from http:// www.conferenceboard.ca/e-library/abstract.aspx?did=7564

Elgar, F. (2003). PhD completion in Canadian universities. Halifax, Canada: University of Dalhousie.

Ferguson, S. J., \& Wang, S. (2014). Graduating in Canada: Profile, labour market outcomes and student debt of the class of 2009-2010. Ottawa, ON: Statistics Canada. Retrieved from http://www.statcan.gc.ca/pub/81-595-m/81-595-m2014101-eng.pdf

Gardner, S. (2009). Student and faculty attributions of attrition in high and lowcompleting doctoral programs. Higher Education, 58(1), 97-112.

Gibbons, M., Limoges, C., Nowotny, H., Schwartzman, S., Scott, P., \& Trow, M. (1994). The new production of knowledge. London, UK: Sage. 
Golde, C. (2005). The role of the department and discipline in doctoral student attrition: Lessons from four departments. Journal of Higher Education, 76(6), 669-700.

Golde, C., \& Dore, G. (2001). At cross purposes: What the experiences of today's doctoral students reveal about doctoral education. A report prepared for The Pew Charitable Trusts, Philadelphia, US.

Golde, C., \& Walker, G. (Eds.). (2006). Envisioning the future of doctoral education: Preparing stewards of the discipline. Carnegie essays on the doctorate. San Francisco, US: Jossey-Bass.

Graff, G. (2006). Towards a new consensus: The PhD in English. In C. Golde \& G. Walker (Eds.), Envisioning the future of doctoral education: Preparing stewards of the discipline (pp. 370-389). San Francisco, US: Jossey-Bass.

Harman, G. (2002). Producing PhD graduates in Australia for the knowledge economy. Higher Education Research \& Development, 21(2), 179-190.

Hessels, L., \& van Lente, H. (2010). The mixed blessing of Mode 2 knowledge production. Science, Technology \& Innovation Studies, 6(1), 65-69.

Jackson, D., \& Michelson, G. (2015). Factors influencing the employment of Australian PhD graduates. Studies in Higher Education, 4O(9), 1660-1678.

Jones, L. (2008). Converging paradigms for doctoral training in the sciences and humanities. In D. Boud \& Lee, A. (Eds.), Changing practices in doctoral education (pp. 29-41). London, England: Routledge.

Kyvik, S., \& Olsen, T. (2012). The relevance of doctoral training in different labour markets. Journal of Education and Work, 25(2), 205-224.

Leonard, D., Metcalfe, J., Becker, R., \& Evans, J. (2006). Review of literature on the impact of working context and support on the postgraduate research student learning experience. Report prepared for The Higher Education Academy, York, UK.

Maheu, L. (2006, November 9-10). Doctoral education and the workings of Canadian graduate schools: A differentiated tier within Canadian universities facing the challenges of tension-driven Functions. Paper presented at Forms Follows Functions: Comparing Forms of Doctoral Training in Europe and North America, Unesco-Cepes and German Rectors' Conference (HRK), Frankfurt, Germany.

Maldonado, V., Wiggers, R., \& Arnold, C. (2013). So you want to earn a PhD? The attraction, realities, and outcomes of pursuing a doctorate. Retrieved from http:// www.heqco.ca/en-ca/Research/ResPub/Pages/Issue-Paper-No-15-Informing-policythrough-analysis-of-current-research.aspx

Maren Wood, L. (2012, October 30). What doors does a PhD in history open? Chronicle of Higher Education. Retrieved from http://www.chronicle.com/article/What-DoorsDoes-a-PhD-in/135448

McAlpine, L. (2016). Why might you use narrative methodology? A story about narrative. Eesti Haridusteaduste Ajakiri. Estonian Journal of Education, 4(1), 32-57.

McAlpine, L., \& Amundsen, C. (2016). Post-PhD career trajectories: Intentions, decision-making and life aspirations. Basingstoke, England: Palgrave Pivot. 
McAlpine, L., Paré, A., \& Starke-Meyerring, D. (2008). Disciplinary voices: A shifting landscape for English doctoral education in the $21^{\text {st }}$ century. In D. Boud \& A. Lee (Eds.), Changing practices of doctoral education (pp. 42-53). London, England: Routledge.

Melin, G., \& Janson, K. (2006). What skills and knowledge should a PhD have? Changing preconditions for PhD education and postdoc work. In U. Teichler (Ed.), The formative years of scholars (pp. 105-118). London, England: Portland Press.

Mellors-Bourne, R., Metcalfe, J., \& Pollard, P. (2013). “What do researchers do?” Early career progression of doctoral graduates. Retrieved from http://www.vitae.ac.uk/CMS/ files/upload/What-do-researchers-do-Early-career-progression-2013.pdf

Neumann, R., \& Tan, K. (2011). From PhD to initial employment: The doctorate in a knowledge economy. Studies in Higher Education, 36(5), 601-614.

Nowotny, H., Scott, P., \& Gibbons, M. (2003). Introduction, Mode 2 revisited: The new production of knowledge. Minerva, 41, 179-194.

Pedersen, H. (2014). New doctoral graduates in the knowledge economy: Trends and key issues. Journal of Higher Education Policy and Management, 36(6), 632-645.

Reissman, C. (2008). Narrative methods for the human sciences. London, England: Sage.

Sfard, A., \& Prusak, A. (2005). Telling identities: In search of an analytic tool for investigating learning as a culturally shaped activity. Educational Researcher, 34(4), 14-22.

Statistics Canada. (2012). Graduate degree recipients from Canadian institutions: Chart 6. CANSIM table 477-0014. Retrieved from http://www.statcan.gc.ca/pub/12-581$\mathrm{x} / 2012000 / \mathrm{c}-\mathrm{g} /$ desc/desc-c-g6-eng.htm

Statistics Canada. (2013). Table A.2: Profile of 2009-2010 graduates by level of study (major fields and selected minor fields). National Graduates Survey, 2013 (Class of 2009-201O). Retrieved from http://www.statcan.gc.ca/pub/81-595-m/2014101/t/ tblA2-eng.htm

Taylor, P. (2008). Being an academic today. In R. Barnett \& R. Napoli (Ed.), Changing identities in higher education: Voicing perspectives (pp. 27-39). London, England: Routledge.

Thiry, H., Laursen, S., \& Loshbaugh, H. (2015). "How do I get from here to there?" An examination of $\mathrm{PhD}$ science students' career preparation and decision making. International Journal of Doctoral Studies, 10, 237-256.

Yang, L., \& Webber, K. (2015). A decade beyond the doctorate: The influence of a US postdoctoral appointment on faculty career, productivity and salary. Higher Education, $70(4), 667-687$.

Yeates, M. (2003, February). Graduate student conundrum. University Affairs, 38-39.

Zhao, C., Golde, C., \& McCormick, A. (2007). More than a signature: How advisor choice and advisor behaviour affect student satisfaction. Journal of Further and Higher Education, 31(3), 263-281. 


\section{Contact Information}

Lynn McAlpine

Educational \& Counselling Psychology

McGill University

lynn.mcalpine@mcgill.ca

Lynn McAlpine is Professor Emerita at McGill University and the University of Oxford as well as Visiting Professor at the University of Lancaster. Her research explores the PhD and post-PhD experiences of early-career researchers both in Canada and Europe.

Nichole Austin is a PhD candidate in Epidemiology at McGill University, where she studies the effect of social policies and neighbourhood-level factors on health outcomes. She served as the TRaCE quantitative analyst from 2016-17. 